\title{
Um "ofício de cartógrafo mestiço": a proposta metodológica de Jesús Martín- Barbero como base para um estudo de caso da telenovela mexicana Rubi
}

Un "oficio de cartógrafo mestizo": la propuesta metodológica de Jesús MartínBarbero como base para um estudio de caso de la telenovela mexicana Rubi

\author{
A "mestizo cartographer's craft": the methodological proposal of Jesús \\ Martín-Barbero as the basis for a case study of the Mexican telenovela Rubi
}

\author{
Ana Lucia Enne' \\ Ohana Boy Oliveira" \\ Joana d'Arc de Nantes"II
}

Palavras chave:

\section{Cartografia}

Mapa das mediações

Metodologia

Telenovela mexicana

Cultura

\section{Resumo:}

Tomando por base as propostas teóricas e metodológicas de Jesús Martín-Barbero, em seus livros Ofício de cartógrafo - Travessias latinoamericanas da comunicação na cultura e Dos meios às mediações: comunicação, cultura e hegemonia, o presente artigo busca discutir a cartografia como inspiração metodológica para se analisar objetos televisivos e suas narrativas na contemporaneidade. A partir desse aporte, pretende-se ilustrar o mapa das mediações a partir das telenovelas mexicanas reprisadas pelo Sistema Brasileiro de Televisão (SBT), com ênfase na produção Rubi, exibida pela quarta vez em 2017. Os itinerários desse estudo se guiam pelas complexas relações entre comunicação, cultura e política, que ocupam um lugar central no mapa das mediações, principalmente no eixo diacrônico entre matrizes culturais e formatos industriais. Dessa forma, inspirada pelos estudos culturais e com uma perspectiva interdisciplinar, a investigação proposta se desenvolve considerando as complexidades da cultura popular segundo a concepção de Stuart Hall e os processos de mediação que a mesma proporciona, exemplificada em alguns produtos midiáticos. 
Resumen:

En base a las propuestas teóricas y metodológicas de Jesús MartínBarbero, en sus libros Oficio de cartógrafo - Travesías latinoamericanas de la comunicación en la cultura y De los medios a las mediaciones: comunicación, cultura y hegemonía, el presente artículo busca discutir la cartografía como inspiración metodológica para analizar objetos televisivos y sus narrativas en la contemporaneidad. A partir de ese aporte, se pretende ilustrar el mapa de las mediaciones a partir de las telenovelas mexicanas reprisadas por el Sistema Brasileño de Televisión (SBT), con énfasis en la producción Rubí, exhibida por cuarta vez en 2017. Los itinerarios de ese estudio se guían por las complejas relaciones entre comunicación, cultura y política, que ocupan un lugar central en el mapa de las mediaciones, principalmente en el eje diacrónico entre matrices culturales y formatos industriales. De esta forma, inspirada por los estudios culturales y con una perspectiva interdisciplinaria, la investigación propuesta se desarrolla considerando las complejidades de la cultura popular según la concepción de Stuart Hall y los procesos de mediación que la misma proporciona, ejemplificada en algunos productos mediáticos.

\section{Palabras clave:}

Cartografia

Mapa de las mediaciones

Metodologia

Telenovela mexicana

Cultura

\section{Keywords:}

Cartography
Map of mediations
Methodology
Mexican telenovela
Culture

\section{Abstract:}

Based on the theoretical and methodological proposals of Jesús Martín-Barbero, in his books Cartographer's Office - Latin American Crossings of Communication in Culture and From Media to Mediations: Communication, Culture and Hegemony, this article seeks to discuss cartography as a methodological inspiration to analyze television objects and their narratives in contemporary times. From this contribution, we intend to illustrate the map of the mediations from the Mexican telenovelas reprinted by the Brazilian Television System (SBT), with an emphasis on Rubi production, exhibited for the fourth time in 2017 . The itineraries of this study are guided by the complex relations between communication, culture and politics, which occupy a central place in the map of mediations, mainly in the diachronic axis between cultural matrices and industrial formats. In this way, inspired by cultural studies and with an interdisciplinary perspective, the proposed research develops considering the complexities of popular culture according to the conception of Stuart Hall and the mediation processes that it provides, exemplified in some media products. 


\section{Um "ofício de cartógrafo mestiço": a proposta metodológica de Jesús Martín-Barbero como base para um estudo de caso da telenovela mexicana Rubi}

\section{Considerações iniciais}

Nos países do Sul o ofício de cartógrafo se desdobra: além de mapas que desenham a terra descoberta se necessita de cartas de mar, ou seja, de navegação por mundos ainda ignorados. No campo intelectual - incluindo nele o acadêmico -, essa tarefa encontra uma de suas figuras-chave no ofício de leitor, o de um leitor que, sem menosprezar o prazer da leitura, aposta numa leitura-trabalho de reconhecimento cultural (MARTíN-BARBERO, 2004, p. 383).

Por que Jesús Martín-Barbero como nossa inspiração metodológica? O pesquisador espanhol, que se estabeleceu academicamente na Colômbia, conjugando em sua formação eixos como a semiologia, a filosofia, a antropologia e os estudos culturais, se auto referia como um "cartógrafo mestiço"Iv. E essa experiência híbrida de mundo se coaduna com a proposta reflexiva que apresenta em muitos de seus trabalhos, em especial Dos meios às mediações e Ofício de cartógrafo, suas obras mais conhecidas no Brasil: a construção da metodologia do "mapa das mediações", ferramenta importante para a análise de diversas narrativas midiáticas, dentre as quais destacamos as televisivas, a partir de categorias-chave, como mediação, mestiçagem, hibridismo, competências e reconhecimento, dentre outras. ${ }^{\vee}$ Sua contribuição é, portanto, uma referência fundamental no campo dos estudos culturais latino-americanos, permitindo olhares mais complexificadores e menos maniqueístas sobre a indústria cultural e seus produtos.

Neste artigo, inspiração e também homenagem, buscamos utilizar suas considerações, tão importantes para os estudos culturais latino-americanos, no sentido de entender suas cartografias acerca da comunicação contemporânea, tomando como estudo de caso a telenovela mexicana Rubi, reprisada no Brasil pela quarta vez em 2017, no Sistema Brasileiro de Televisão (SBT), o que faremos na última parte deste texto.

Outro expoente dos estudos culturais latino-americanos, Nestor García Canclini (ele também um "cartógrafo mestiço", um híbrido em sua trajetória e formação teórica), definiu Dos meios às mediações: comunicação, cultura e hegemonia (publicado originalmente na Espanha em 1987 e, no Brasil, em 1997) como um livro "escrito para confundir os bibliotecários", vi porque não está situado exclusivamente em uma disciplina específica, seja sociologia, antropologia, comunicação, mas servindo a todas elas, trazendo contribuições importantes para cada campo de pesquisa mencionado. Nesse sentido, um dos primeiros pontos que gostaríamos de destacar diz respeito à transdisciplinaridade de suas obras no estudo da comunicação (hibridizando também sua mestiçagem enquanto pensador com a metodologia proposta):

[...] que de modo algum significa a dissolução dos problemas-objeto do campo da comunicação nos de outras disciplinas sociais, mas a construção das articulações e intertextualidades que fazem possível pensar as mídias e as demais indústrias culturais como matrizes de desorganização e reorganização da experiência social e da nova trama de atores e estratégias de poder (MARTíN-BARBERO, 2004, p. 249). 
Essa perspectiva faz parte, de certa maneira, de certa "tradição" dos estudos culturais, ao reunir diversas disciplinas para pensar a relação entre cultura, poder e sociedade e suas variáveis políticas e econômicas, considerando os embates, as disputas, as negociações e as resistências envolvidas. VII Ao pensar os caminhos da comunicação nas últimas décadas, Martín-Barbero traz importantes pistas epistemológicas para refletir sobre o passado, o presente e o futuro deste campo, procurando "deslocar as fronteiras erigidas por disciplinas, cânones e hierarquias dos saberes, racionalidades políticas ou evidências tecnológicas" (MARTíN-BARBERO, 2004, pp. 241-242).

Desde os mosteiros medievais até as escolas de hoje o saber, que foi sempre fonte de poder, tem conservado esse duplo caráter de ser por sua vez centralizado territorialmente e associado a determinados suportes e figuras sociais. Daí que as transformações nos modos como circula o saber constitua uma das mais profundas mutações que uma sociedade pode sofrer (MARTÍN-BARBERO, 2004, p. 340).

Martín-Barbero dedicou-se, em seus trabalhos, dentre outros temas, aos estudos de telenovela, que o fizeram ser uma referência não só nesta área, mas também nos estudos culturais latino-americanos de maneira geral, já que o autor vem complexificando o debate sobre televisão, problematizando a questão de gosto acerca dessas narrativas audiovisuais, criticando com embasamento a indústria cultural e valorizando a cultura popular e suas subjetividades. Sobre tal ponto, o autor afirma que o que lhe interessa não é o sucesso de determinado programa de televisão,

mas o des-centramento do olhar que nos possibilita indagar o que, na comunicação, há do mundo da gente comum: tanto do lado dos produtores, negociando entre as lógicas do sistema comercial - estandardização e rentabilidade - e as dinâmicas da heterogeneidade cultural dos países e das regiões, como do lado dos espectadores e seus parentescos de leitura configurando comunidades hermenêuticas a partir das diversas competências culturais que atravessam os haveres e saberes, os imaginários e as memórias de classe, de etnia, de gênero, de idade (MARTíN-BARBERO, 2004, p. 26).

A partir desses postulados epistemológicos e políticos, que enfatizam o mestiço, o híbrido, as negociações e competências culturais, Martín-Barbero desenvolveu suas bases metodológicas, dentre as quais destacam-se o circuito das mediações e a proposta da cartografia, esta última apresentada em especial no livro Ofício de cartógrafo: Travessias latino-americanas da comunicação na cultura (publicado originalmente em 2002, na Espanha, e posteriormente no Brasil em 2004), sobre as quais falaremos mais detalhadamente a seguir.

\section{Mediação e cartografia como inspiração metodológica}

As contribuições de Martín-Barbero têm grande significação para os estudos de recepção na América Latina (JACKS; MENEZES, 2007, p. 9). Em 1987, na obra De los medios a las mediaciones, Martín-Barbero propôs uma mudança no enfoque das reflexões sobre comunicação, em que as pesquisas não se concentrariam a "partir da análise das lógicas de produção e recepção, para depois procurar suas relações de imbricação ou enfrentamento" (MARTÍN-BARBERO, 2009b, p. 294). A proposta seria de que o debate se moveria dos meios para as mediações, ou seja, "para as articulações entre práticas de co- 
municação e movimentos sociais, para as diferentes temporalidades e para a pluralidade das matrizes culturais" (MARTíN-BARBERO, 2009b, p. 261). Portanto, sugerindo direcionar o olhar para além dos meios ou receptores, buscando observar onde os sentidos são produzidos e atentar para as "mediações". Martín-Barbero acrescentou que as mediações são o "lugar" que permite compreender a interação entre o espaço da produção e o da recepção. Trata-se, portanto, do lugar de onde "provêm as construções que delimitam e configuram a materialidade social e a expressividade cultural da televisão" (MARTíN-BARBERO, 2009b, p. 294). Assim, sem perder de vista as estruturas, com o conceito de mediações o autor nos convoca a pensar também o mundo do receptor, suas leituras e práticas, suas competências e "modos de fazer com" (no sentido proposto por Michel de Certeau), suas reconversões (termo fundamental na proposta teórica-metodológica de Canclini, a quem já nos referimos neste artigo), suas apropriações (também conceito-chave para alguns nomes fundantes de campos de estudo da cultura, como Roger Chartier, Peter Burke, Robert Darnton, dentre outros). Evitando as dicotomias e binarismos, a atenção em relação aos lugares de mediação não esvazia a crítica aos meios de comunicação hegemônicos nem perde de vista as estratégias ideológicas e de dominação política e econômica em torno da indústria cultural na América Latina, mas amplia essa abordagem, permitindo perceber as matrizes culturais que alimentam tais produções, as múltiplas configurações possíveis e o mundo da recepção, em que se estabelecem outros usos e mediações, para além dos pretendidos.

Sob essa perspectiva, Martín-Barbero sugere três lugares de mediação. $\mathrm{O}$ primeiro é a cotidianidade familiar, ambiente em que ocorrem conflitos e tensões, entendido pelo autor como um lugar social fundamental para abordagem dos setores populares (MARTÍN-BARBERO, 2009b, p. 295). O autor destaca, contudo, que essa mediação não se restringe à esfera da recepção, uma vez que se inscreve também no discurso televisivo. Já o segundo lugar de mediação corresponde à temporalidade social, que se refere à aproximação do tempo de programação da televisão com o tempo cotidiano, ambos regidos por uma lógica de repetição e fragmentos. Isto é, esse lugar de mediação indica como a televisão se aproxima da rotina dos receptores para gerar lucro. O terceiro lugar de mediação proposto é a competência cultural, que "diz respeito a toda vivência cultural que o indivíduo adquire ao longo da vida, não apenas através da educação formal, mas por meio das experiências adquiridas em seu cotidiano" (WOTTRICH; SILVA; ROSSINI, 2009, p. 9), de tal modo que a mesma pode também ser acionada quando se assiste à televisão.

Três anos após a publicação do livro De los medios a las mediacones, em 1990, Martín-Barbero apresenta uma atualização da reflexão acerca das mediações no artigo "De los medios a las praticas", em que propõe transformar os lugares de mediação em dimensões, sendo elas: a sociabilidade (ou socialidade), a ritualidade e a tecnicidade.

A sociabilidade refere-se à interação social permeada pelas constantes negociações do indivíduo com o poder e com as instituições. A ritualidade relaciona-se com as rotinas do trabalho imbricadas com a produção cultural. Já a tecnicidade refere-se às características do próprio meio (WOTTRICH; SILVA; ROSSINI, 2009, p. 4).

Embora essas dimensões sejam subsequentes temporalmente aos lugares de mediação elaborados em 1987, Martín-Barbero não estabeleceu uma relação direta entre os termos (RONSINI, 2010, p. 6). 
Ainda na década de 1990, em "Pistas para entre-ver meios e mediações" ([1998] 2009), "VIII o pesquisador deu continuidade a essas reflexões e apresentou um novo mapa das mediações, que anos mais tarde foi consolidado na obra Ofício do Cartógrafo. Construído a partir de uma necessidade de se pensar um mapa que conseguisse abranger a "complexidade nas relações constitutivas da comunicação na cultura" (MARTíN-BARBERO, 2004, p. 229), tendo em vista que "as mídias passaram a constituir um espaço-chave de condensação e intersecção da produção e do consumo cultural, ao mesmo tempo em que catalisam hoje algumas das mais intensas redes de poder" (MARTíN-BARBERO, 2004, p. 229), o autor propôs sua metodologia complexificadora, como detaIharemos a seguir.

O novo esquema (Figura 1) acrescenta às três mediações - a sociabilidade (ou socialidade), a ritualidade e a tecnicidade - uma quarta: a institucionalidade, imbricada de interesses e poderes contrapostos que afetam continuamente a regulação de discursos (MARTíN-BARBERO, [1997] 2009b, p. 17). Segundo Martín-Barbero, a comunicação "vista a partir da institucionalidade [...] se converte em questão de meios, isto é, de produção de discursos públicos cuja hegemonia se encontra hoje paradoxalmente do lado dos interesses privados" (MARTÍN-BARBERO, [1997] 2009b, p. 18).

As novas mediações, então, são dispostas em meio a um mapa (Figura 1), configurado a partir de dois eixos: o diacrônico ou histórico de longa duração, que é tensionado pelas relações entre as Matrizes Culturais e os Formatos Industriais; e o sincrônico, que é tensionado pelas relações entre as Lógicas de Produção e as Competências de Recepção ou Consumo.

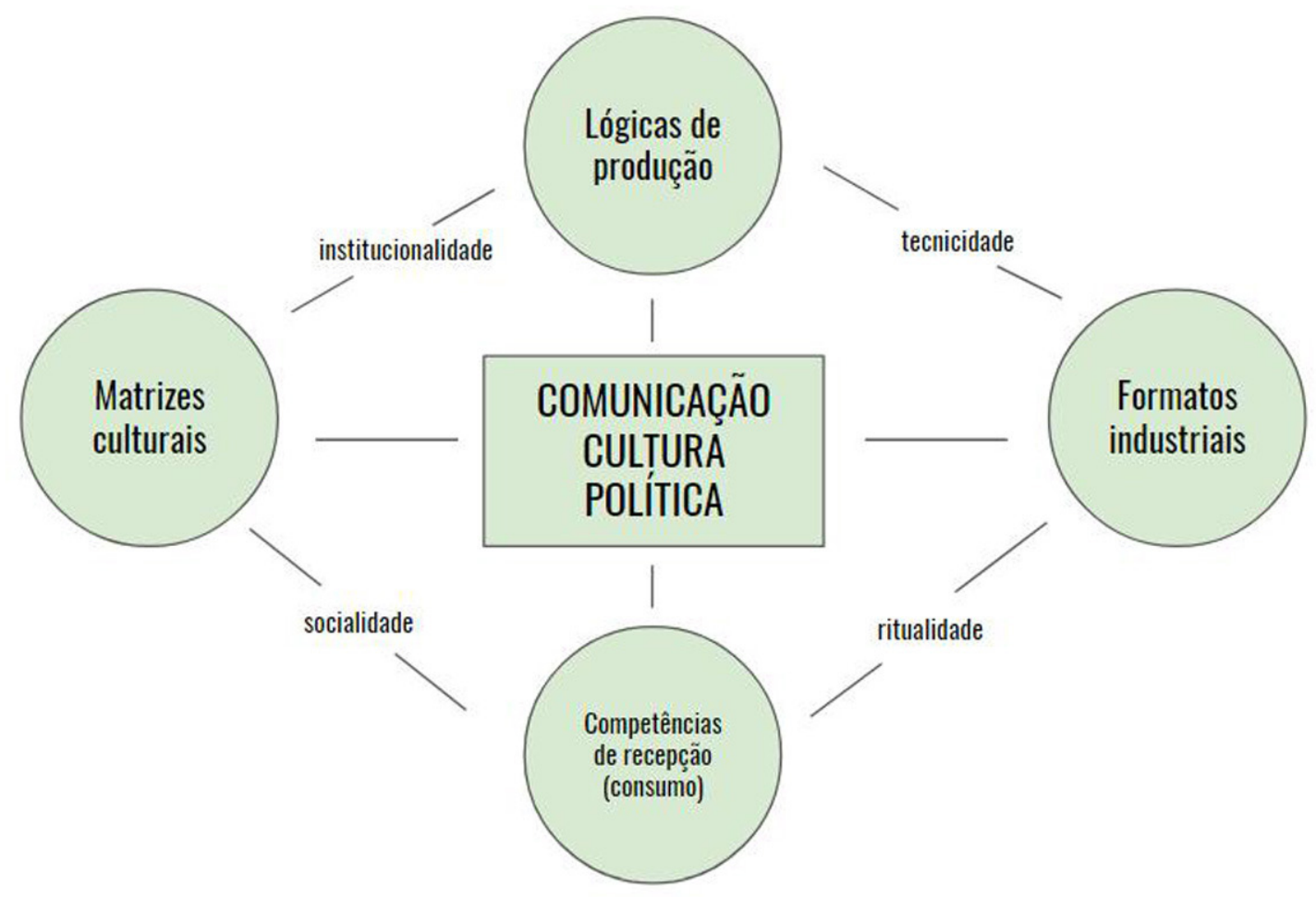

Figura 1 - Mapa das mediações comunicativas da cultura

Fonte: MARTíN BARBERO, 2009a; p.16, versão de desenho elaborado pelas autoras 
Levando em consideração tais postulados teóricos e a trajetória acadêmica desse "cidadão latino-americano nascido na Espanha" em 1937,'X podemos afirmar que a proposta de cartografia segue então diversos aspectos, dentre eles: os contextos local e global; ${ }^{X}$ suas experiências pessoais diversas com alguns territórios através dos deslocamentos entre vários países e universidades; sua visão de mundo, ou seja, o lugar de onde está falando, de onde parte seu discurso e pensamento, além dos atravessamentos aos quais está suscetível. Dessa maneira, o autor afirma:

Minha extraviada aventura pelos caminhos da comunicação não estaria completa sem traçar as móveis linhas de outro mapa: o de minhas sucessivas des-territorializações, não intelectuais ou virtuais, mas corporais [...]. E o que esse périplo marca não são meras etapas de uma viagem mas verdadeiras des-territorializações e re-colocações, tanto da experiência como do lugar desde onde se pensa, se fala, se escreve (MARTíN-BARBERO, 2004, p. 28).

Nesta citação, explicita-se de forma clara porque é preciso ser um cartógrafo para compreender os processos culturais em torno da indústria cultural: porque estamos diante de uma questão espacial, de território, de lugar. Os processos híbridos envolvem deslocamentos, trânsito, passagens entre territórios, movimentos contínuos de territoralizações, des-territorializações e re-territorializações, implicando em entender de maneira complexa como se formam e são ocupados os lugares, inclusive os de fala. Para dar conta dessa dimensão espacial, é preciso saber esquadrinhar, compreender, mapear esses territórios e lugares, daí a necessidade de uma cartografia como aporte metodológico.
Porém, como o autor detalhará, não estamos diante de contextos claros, exatos, de inspiração da cartografia hegemônica, capaz de fornecer mapas exatos, planos, coerentes. Estamos diante de complexos jogos de construção cultural, mestiços e híbridos, que exigem que o ofício de cartógrafo implique em perspectivas transdisciplinares e translocais, um desafio constante de construir mapas noturnos, não iluminados pelo dado, mas tateados, experimentados, sentidos. É preciso, diz Martín-Barbero, "avançar tateando, sem mapa ou tendo apenas um mapa noturno. Um mapa que sirva para questionar as mesmas coisas - dominação, produção e trabalho - mas a partir do outro lado: as brechas, o consumo e o prazer" (1997, p. 288, grifo do autor). A dimensão do sensível, do tátil, do corpo, do sensório, também precisa ser acionada. Neste sentido, podemos aproximar a metodologia proposta por Martín-Barbero da tradição de estudos culturais de Mikhail Bakhtin, em que o corpo, as ambivalências, as circularidades entre os elementos, o hibridismo, são categorias fundamentais para a compreensão das práticas culturais sem que se caia na fácil e reducionista armadilha das leituras binárias, que inclusive separam as análises racionais e isentas dos fenômenos midiáticos das práticas diárias e sensórias da vida comum. Ambos os autores de inspiração marxista, tanto Bakhtin quanto Martín-Barbero recusam as análises que desprezam as experiências e as apropriações, introduzindo como fundamental a compreensão dos gêneros discursivos e matrizes culturais na produção midiática e as mediações exercidas tanto no mundo dos emissores quanto dos receptores. Assim, seria preciso

desenhar um novo mapa de problemas em que caiba a questão dos sujeitos e das temporalidades sociais, isto é, a trama da modernidade, descontinuidades e transformações do sensorium 
que gravitam em torno dos processos de constituição dos discursos e dos gêneros nos quais se faz a comunicação coletiva (MARTíN-BARBERO, 2004, p.212, grifos do autor).

Assim, pensar a cartografia como inspiração metodológica significa partir das propostas dos mapas criados por Martín-Barbero para discutir os caminhos de análise a serem seguidos e complexificados, começando por "movimentar a análise das relações entre comunicação e cultura das mídias em direção à questão e ao âmbito das mediações" (MARTíN-BARBERO, 2004, p. 316).

Pois, ainda que confundida com as mídias - tecnologias, circuitos, canais e códigos -, a comunicação remete hoje, como o fez ao longo da história, aos diversos modos e espaços de reconhecimento social. E é por relação a esses modos e espaços que se fazem compreensíveis as transformações sofridas pelas próprias mídias e seus usos (MARTÍN-BARBERO, 2004, p. 316).

Para contextualizar nosso campo de pesquisa, que está relacionado à televisão, precisamos discutir o conceito de cultura popular ${ }^{\mathrm{XI}}$, tomando com ponto de partida as colocações de Stuart Hall, que pensa a cultura como arena de disputas, ou seja, um misto entre"conter e resistir", na qual operam resistências, enfrentamentos, mas também negociações e apropriações. Nas palavras de Martín-Barbero, estamos diante de um processo complexo de "sedução e negação". Assim, levando em conta que a cultura popular é "o terreno sobre o qual as transformações são operadas" (HALL, 2009, p. 232), ao estudar esse campo, precisamos considerar seu duplo interesse, "o duplo movimento de conter e resistir, que inevitavelmente se situa em seu interior" (HALL, 2009, p. 233).
Dessa forma, "não existe uma 'cultura popular' íntegra, autêntica e autônoma, situada fora do campo de força das relações de poder e de dominação culturais" (HALL, 2009, p. 238), pois a dialética da luta cultural

é contínua e ocorre nas linhas complexas da resistência e da aceitação, da recusa e da capitulação, que transformam o campo da cultura em uma espécie de campo de batalha permanente, onde não se obtêm vitórias definitivas, mas onde há sempre posições estratégicas a serem conquistadas ou perdidas (HALL, 2009, p. 239).

Portanto, enquanto "arena do consentimento e da resistência" (HALL, 2009, p. 246), a cultura popular continua sendo um importante campo a ser analisado. Segundo Omar Rincón (2015, p. 24, tradução nossa), "esta ambiguidade e multiplicidade de significados da cultura popular aparece porque ela dá conta de muitas práticas, processos e experiências diversas"XII, ou seja, tentar simplificar seus diversos sentidos em determinados moldes não dá conta de suas complexidades.

Omar Rincón, ao considerar as culturas populares como "bastardas", aciona a ideia de culturas híbridas de Nestor García Canclini, as mediações no popular de Jesús Martín-Barbero e a perspectiva intersticial de entre-lugar de Homi K. Bhabha. Após analisar brevemente tais concepções, o teórico considera que tais pesquisadores seriam os três "pais" dessas concepções acerca das"culturas bastardas", pois, ao problematizaremeste campo de produção do conhecimento, estes pensadores abandonaram o pensamento dualista e essencialista, assumindo os espaços intermediários e de mistura, considerando suas ambiguidades e problemáticas. Após esta explanação teórica, adentramos no estudo de caso da telenovela 
mexicana Rubi, exibida pela quarta vez no SBT, em 2017.

\section{Estudo de caso da telenovela mexicana Rubi}

Para o desenvolvimento da análise proposta, buscamos refletir, a partir da telenovela Rubi, os aspectos das lógicas de produção, das matrizes culturais e dos formatos industriais, bem como as mediações que atravessam essas esferas (a institucionalidade e a tecnicidade). ${ }^{\mathrm{XIII}}$ É fundamental acrescentar que não desenvolvemos o nosso estudo buscando separar de maneira cristalizada cada um desses pontos, pelo contrário, acreditamos que todos os aspectos se entrecruzam e se ligam, tal como mostram os eixos que cruzam o mapa de Martín-Barbero. Dessa forma, utilizamos o mapa como um guia cartográfico para construção desta análise.

A telenovela analisada, Rubi, foi exibida originalmente em 2004 na rede de televisão Televisa, no México. No Brasil, a primeira transmissão ocorreu em 2005 no SBT, que reprisou a trama nos anos 2006, 2013 e 2017. A trama tem como protagonista uma vilã, de nome Rubi, uma mulher de origem popular, mas muito "ambiciosa" e que deseja aumentar seu padrão de vida e não mede esforços para alcançar seu objetivo. Ela é bolsista em uma Universidade particular e finge, por interesse, ser amiga de uma jovem rica chamada Maribel. No decorrer da trama, Rubi se apaixona pelo melhor amigo do noivo de Maribel, que é um médico recém formado. Ela acha que ele é rico e fica muito feliz por ter encontrado o amor e a riqueza. Porém, ele também é pobre e, quando Rubi descobre, abre mão de ficar com ele, rouba o noivo da amiga (que é rico) e assim se desenvolve a trama principal.
Rubi é construída a partir da matriz cultural do melodrama clássico. Martín-Barbero (1997) descreve esse melodrama, que começa a surgir na Europa no século XVIII, como um "grande espetáculo popular". Ele explica que nesse período o gênero condiz mais com apresentações de feiras, e seus temas se aproximam mais das narrativas da literatura oral, especialmente dos contos e relatos de medo, terror e mistério (MARTÍN-BARBERO, [1997] 2009b, p. 157-158). Neste sentido, o melodrama atua como matriz cultural, mediando a recepção ao acionar elementos de conhecimento discursivo para reconhecimento cultural na recepção.

Há, nesse contexto, outra particularidade que reflete nas encenações melodramáticas. Trata-se das medidas governamentais na França e Inglaterra que proibiram a existência de teatros populares, visando conter o alvoroço e preservar o "verdadeiro" teatro. Assim, os teatros oficiais eram exclusividade das classes econômicas altas e ao povo restavam representações sem falas e nem mesmo cantos. Fato este que perdurou até 1806 (MARTÍN-BARBERO, [1997] 2009b, p. 158). Dessa forma, segundo Silva (2012), isso proporcionou que o "[...] gênero desenvolvesse os artifícios visuais e sonoros em detrimento da linguagem falada, o que facilitou, portanto, sua posterior adaptação para o cinema e a televisão" (SILVA, 2012, p. 161).

Apesar de ser considerado um gênero teatral popular, não eram apenas as classes populares que apreciavam o melodrama. De acordo com Thomasseau, no contexto de pós Revolução Francesa, "a ética melodramática realiza [...] os desejos de todas as classes da população" (THOMASSEAU, 2012, p. 14). Ele relata que a classe popular se reconhece no gênero, na medida em que a vítima triunfa contra o opressor; a burguesia estima o 
culto aos valores tradicionais e à honra presentes nas obras; e a aristocracia admirava as apresentações que conservavam a hierarquia e afirmavam a existência de um poder estabelecido.

Salientamos, ainda, que, devido à Revolução Francesa, a população vivenciou muitas experiências assustadoras e intensas, que acenderam a imaginação e a sensibilidade de certos grupos. O surgimento do melodrama, então, possibilitou que essas emoções fossem representadas através do triunfo da vítima sobre o traidor. Conforme ressalta Martín-Barbero, nessas circunstâncias, o melodrama manifesta-se, então, como "o espelho de uma consciência coletiva" (1997, p. 158).

Retomando as reflexões sobre a telenovela pesquisada, destacamos na mesma essa presença de um opressor e um oprimido. Há, portanto, a existência de uma dimensão maniqueísta, com a divisão das figuras do "bom" versus o "mau", notória através das figuras de Rubi (a vilã) versus Maribel (a mocinha). Além disso, tal qual sua matriz cultural fundante, há um caráter pedagógico, no qual os personagens bons - como a Maribel não mudam suas virtudes e suas ações e falas reforçam a importância dos valores tradicionais. Enquanto os personagens maus, que traem a virtude, a honra e a moralidade - como Rubi - serão castigados, demonstrando que não servem de exemplo para o público.

Associado a essas questões morais imbricadas na trama, acreditamos que é fundamental uma reflexão sobre as implicações imersas nas lógicas de produção e nos formatos industriais. Nesse sentido, acreditamos que é importante analisar a emissora de origem (Televisa), bem como o formato difundido por ela, e a emissora no Brasil (SBT). Sobre essa primeira rede de TV, é necessário pontuar que ela apresenta como uma das características de suas produções o conservadorismo. A pesquisadora Nora Mazziotti (2006) aponta que o modelo mexicano, em especial aquele desenvolvido pela Televisa, apresenta ainda características fundamentais, tais como: 1) a moralidade católica como um ponto determinante - as expressões de religiosidade estão sempre presentes e só se alcança a redenção através do sofrimento; 2) os valores morais estabelecidos são respeitados e com isso as transgressões são castigadas e não há espaço para novos pontos de vista; 3) as histórias têm alto nível de obviedades, que podem torná-las tanto engraçadas quanto comoventes; 4) não há lugar para erotismo nas tramas, - a sensualidade é associada ao vilão e deve ser vista como algo negativo; 5) os personagens normalmente são arquetípicos (entre eles, são comuns a mãe, a vilã, a inocente, o ambicioso, entre outros) e apresentam caracteres imutáveis os quais são revelados não só através da atuação mas também da maquiagem e do figurino.

Atualmente, pode-se afirmar que algumas produções mexicanas estão apresentando modernizações. Nota-se a inclusão de personagens híbridos, ou seja, não são inteiramente bons ou ruins. Há também a apresentação de situações relacionadas com fatos reais e em voga na sociedade mexicana. O gênero mistura-se com outros, gerando novos tipos de telenovela. Contudo, salienta-se que embora atualmente estejam sendo apresentados tipos mais diversificados de tramas mexicanas, o modelo clássico ainda é predominante e, em todas as tramas, mesmo as modernas, se mantém a estrutura básica do melodrama.

Relacionado ao aspecto de modernizações das tramas mexicanas, é importante destacar o contexto sociocultural em que essas produções são 
feitas. O México é um país que possui uma relevante parcela da população religiosa (catolicismo apostólico romano) e conservadora. Nesse sentido, determinados temas causam insatisfação nessa parte do público. Um exemplo foi o caso ocorrido em outubro de 2017, quando a Televisa transmitiu Papá a toda madre (2017), uma trama que trazia como personagens um casal homossexual casado legalmente e que desejava constituir família e se tornar pais. Nessa mesma trama, a rede de TV mexicana exibiu o primeiro beijo gay em uma telenovela de horário nobre. A contestação sobre o plot do casal gay gerou um abaixo assinado com mais de 37 mil assinaturas ${ }^{X I V}$ para que a telenovela parasse de ser exibida. Essa resistência à diversidade sexual pode refletir em futuras produções e esses temas podem ser polidos ou até mesmo deixarem de ser abordados, tendo em vista que as telenovelas são tramas abertas e, em alguma medida, os anseios dos telespectadores são levados em consideração pelos autores, o que constitui, na proposta cartográfica de Jesús Martín-Barbero, não um efeito da produção, mas parte constitutiva do processo, já que os receptores também mediam, em instâncias múltiplas, o produto.

No caso de Rubi, muito embora contasse com a presença de um personagem homossexual, a ele cabia apenas o caráter cômico. Como "braço direito" de Rubi, o personagem não tinha um par romântico, apenas acompanhava a vilã e falava em momentos de tensões frases que "suavizavam" o clima da cena, configurando o arquétipo do "bobo", elemento fundamental na construção do melodrama, como explica Martín-Barbero. O que se pode associar a esse aspecto é o período em que foi produzida essa narrativa, treze anos antes do primeiro beijo gay em horário nobre. Um momento em que não havia ocorrido a legalização do casamen- to entre pessoas do mesmo sexo e, possivelmente, uma fase em que o conservadorismo dos telespectadores no México era ainda maior.

Perpassando o olhar para o SBT, a emissora brasileira em que Rubi foi exibida, pontuamos a construção de sua identidade como uma emissora de alcance de setores "populares" do público (MIRA, 1995), desenvolvida há mais de 35 anos, através de uma grade de programação composta, por exemplo, por programas de auditório - que são gravados como se fossem ao vivo, com poucas edições e incorporam a participação da plateia, bem como do público de casa através do posicionamento de câmera e fala do apresentador -, telejornais "populares" - nos quais os jornalistas têm uma postura e demonstram indignação com problemas enfrentados pela população - e telenovelas mexicanas. Sobre esta última atração, acreditamos que ao priorizar por uma narrativa baseada no melodrama clássico, a rede de TV reforça o caráter "popular" presente desde sua fundação.

Assim, é possível perceber, tanto no produto escolhido, a telenovela "Rubi", quanto na emissora brasileira na qual ele é veiculado, a relação da indústria cultural com matrizes fundantes das culturas populares, em contextos originais nos quais as relações dialéticas entre "conter e resistir" se fizeram muito presentes. Tais matrizes serão reelaboradas na produção industrial midiática, a partir de lógicas de produção, resultando em formatos industriais, veiculados dentro de um sistema capitalista de mídia, no qual os objetivos ideológicos, políticos e econômicos estão colocados. Mas, a partir da proposta cartográfica de Martín-Barbero, dentre outras possíveis que também aqui citamos, é possível perceber esse processo sem reduzi-lo a uma simplificação do tipo "produto fabri- 
cado de cima para baixo visando alienar o consumidor", nem tampouco a uma glorificação do tipo "a cultura de massa oferece a cultura que o povo gosta", resumindo de forma simplista dois lugares analíticos históricos, que foram consagrados por Umberto Eco como "apocalípticos" e "integrados" e que perduram até os dias atuais, a despeito dos intensos e renovadores debates teóricos e metodológicos que foram travados.

O que os estudos culturais propuseram, e é nesta tradição que encontra-se o mapa das mediações de Martín-Barbero, para escapar desse binarismo reducionista e pouco explicativo, é que se considere de forma mais densa o processo, indo das matrizes aos receptores, para depois retornar às matrizes, em um círculo hermenêutico como proposto, por exemplo, pela teoria da tríplice mimese de Paul Ricoeur. Em que a configuração, no caso analisado, a novela "Rubi", seja compreendida a partir dos elementos que a prefiguraram, suas matrizes culturais, mediadoras dessa tessitura, que, no entanto, para chegar ao seu formato industrial, também passa por mediações da lógica de produção, se configurando como produto híbrido, que só se realizara na re-figuração, no mundo do receptor/leitor/ouvinte/espectador, que, por sua vez, também mediará esse processo, através de competências culturais diversas.

Exatamente por isso, a lógica da produção, tentando controlar os efeitos de sentido, deverá levar em conta essas competências, dialogando com as matrizes antecedentes e buscando antecipar os discursos que se sucedem, em processos dialógicos e polifônicos, como descreve Bakhtin. No entanto, não há garantias de que tais efeitos de sentido irão se consolidar em práticas, porque como sujeitos no mundo também os receptores irão mediar aquela tessitura narrativa e reconfigurá-la, constituindo categorias que se embrenharão, através das práticas culturais nas arenas de disputas, com as matrizes culturais fornecidas. Assim, o circuito se completa, embora sempre aberto e em processo.

Dessa forma, para darmos conta do mapa das mediações em sua plenitude, como proposto por Martín-Barbero, precisaríamos bem mais do que os limites possíveis desse artigo, buscando as mediações receptoras e suas interlocuções com as matrizes culturais. Como isso não seria possível, percorremos parte do processo, buscando perceber as hibridizações e mestiçagens entre as matrizes culturais e os produtos midiáticos industrializados, tomando como referência a novela mexicana Rubi. Mas, mesmo não completando o circuito metodológico, acreditamos ter trazido aqui as reflexões do autor até um ponto possível, não deixando de pontuar, em termos teóricos, como o processo deveria ser realizado.

\section{Considerações finais}

Diante do exposto nesta investigação, a tentativa foi seguir os caminhos cartográficos de Martín-Barbero para pensar um objeto de pesquisa de matrizes melodramáticas, inserido na indústria cultural latino-americana. Para tanto, uma das formas foi trilhar o caminho interdisciplinar para entender as complexidades dos objetos televisivos.

Tão decisiva quanto a assunção explícita do "tema" das mídias e das indústrias culturais pelas disciplinas sociais é a consciência crescente do estatuto transdisciplinar do campo, tornado evidente pela multidimensionalidade dos processos comunicativos e sua gravitação a cada dia mais forte em torno dos movimentos 
de desterritorialização e hibridações que a modernidade latino-americana produz (CANCLINI apud MARTÍN-BARBERO, 2004, p. 219).

Outro ponto relevante a ser destacado está relacionado ao fato de pesquisarmos produtos midiáticos da televisão para discutir questões sociais contemporâneas, entendendo os embates que se dão entre a grande estrutura das emissoras no Brasil, com seu grande alcance de público, tanto na televisão quanto na internet, $\mathrm{xV}$

Pois sabemos que a luta através das mediações culturais não dá resultados imediatos e espetaculares, mas é a única garantia de que passemos do simulacro da hegemonia ao simulacro da democracia: evitar que uma dominação derrotada possa ressurgir nos hábitos cúmplices que a hegemonia instalou em nosso modo de pensar e nos relacionar (CANCLINI apud MARTÍN-BARBERO, 2004, p. 212).

Fugindo da dualidade nas análises das narrativas televisivas, buscamos trazer para o debate as ambivalências de tais produções e mostrar a complexidade dos processos culturais na contemporaneidade. Concordamos que tais processos envolvem a comunicação, a cultura e a política, segundo Martín-Barbero,

porque a mídia não se limita a veicular ou traduzir as representações existentes, nem pode tampouco substituí-las, senão que tem entrado para constituir uma cena fundamental na vida pública. Nas mídias se faz, e não somente se fala, a política" (MARTíN-BARBERO, 2004, p. 321).

Ressaltando esses atravessamentos, ao discorrer sobre o contexto de globalização na América Latina, Martín-Barbero traz uma reflexão que continua atual:
[...] a cultura emerge como o espaço estratégico das tensões que desgarram e recompõem o "estar juntos", os novos sentidos que adquirem o laço social, e também como lugar de ajuntamento e hibridação de todas as suas manifestações: religiosas, étnicas, estéticas, políticas, sexuais. Daí que seja desde a diversidade cultural das histórias e dos territórios, das experiências e das memórias, que se resiste, e se negocia e interatua com a globalização, e desde onde se acabará por transformá-la (MARTíN-BARBERO, 2004, p. 365-366).

Desta maneira, inspiradas pelos estudos culturais, nos guiamos pelos caminhos epistemológicos de Jesús Martín-Barbero para pensar a cultura em diálogo com a comunicação e a política, entendendo que a necessária análise de produtos/ objetos midiáticos, para se refletir sobre a sociedade contemporânea, no nosso caso, a latino-americana, precisa ser cada vez mais complexificada, discutindo assim novos modos de ser sul através das territorialidades, afetos e poderes.

\section{Bibliografia}

BAKHTIN, Mikhail. A Cultura Popular na Idade Média e no Renascimento: o contexto de François Rabelais. São Paulo: Hucitec ; Brasília: Universidade de Brasília, 1987.

BHABHA, Homi. O local da cultura. Belo Horizonte: Editora UFMG, 1998.

BURKE, Peter. A cultura popular na Idade Moderna. Europa - 1500-1800. São Paulo: Companhia das Letras, 1989. 
CANCLINI, Nestor. Culturas Híbridas. São Paulo: Edusp, 1998.

CERTEAU, Michel de. A invenção do cotidiano. Petrópolis: Vozes, 1994.

CHARTIER, Roger. A História Cultural: entre práticas e representações. Lisboa: Difel/Bertrando Brasil, 1990.

HALL, Stuart. Da diáspora: identidades e mediações culturais. Belo Horizonte: Editora UFMG, 2009.

JACKS, Nilda; MENEZES, Daiane Boelhouwer. Estudos de recepção na América Latina: contribuição para atualizar o panorama. E-Compós (Brasília), v. 1, p. 1-12, 2007. Disponível em: <http://ltc-ead.nutes.ufrj.br/constructore/objetos/Estudos $\% 20$ de $\% 20$ Recep $\%$ e $7 \%$ e $30 \% 20$ na\%20Am\%e9rica\%20Latina.pdf>. Acesso em: 10 nov. 2017.

MARTÍN-BARBERO, Jesús. As formas mestiças da mídia. Entrevista a Mariluce Moura, Revista Pesquisa FAPESP, p. 10-15, 2009a. Disponível em <http://revistapesquisa.fapesp.br/wp-content/ uploads/2009/09/010-015_entrevista_163.pdf>. Acesso em: 10 nov. 2017.

MARTÍN-BARBERO, Jesús. Dos Meios às Mediações: comunicação, cultura e hegemonia. Rio de Janeiro: Editora UFRJ, [1997] 2009b.

MARTÍN-BARBERO, Jesús. Ofício de cartógrafo: Travessias latino-americanas da comunicação na cultura. São Paulo: Edições Loyola, 2004.

MARTINS, Rafael Barbosa Fialho. Resgate Histórico das Vinhetas do SBT: A Busca por um "Estilo SBTista". Revista Eletrônica CoMtempo, São Paulo, v. 6, n 2, p. 1-16, 2014.

MIRA, Maria Celeste. Circo eletrônico: Silvio Santos e o SBT. São Paulo: Loyola, 1995.

MAZZIOTTI, Nora. Telenovela: Industria y Prácticas Sociales. Buenos Aires: Grupo Editoral Norma, 2006.

NANTES, Joana d'Arc de. Audiência da telenovela mexicana no Brasil: o caso de A Usurpadora. (Graduação em Estudos de Mídia). Universidade Federal Fluminense, 2016.

OLIVEIRA, Ohana. "O que o mundo separa, o Esquenta! junta?": como representações e media- ções ambivalentes configuram múltiplos territórios. (Mestrado em Cultura e Territorialidades). Universidade Federal Fluminense, 2015.

RICOEUR, Paul. A tríplice mimese. In: Tempo e Narrativa. Campinas: Papirus, 1984

RINCÓN, OMAR. Lo popular en la comunicación: culturas bastardas + ciudadanías celebrities. In: La comunicación en mutación [Remix de discursos]. Bogotá: FES, 2015.

RONSINI, Veneza Mayora. A perspectiva das mediações de Jesús Martín-Barbero (ou como sujar as mãos na cozinha da pesquisa empírica de recepção). In: $19^{\circ}$ Encontro Anual da COMPÓS, 2010, Rio de Janeiro. Anais do $19^{\circ}$ Encontro Anual da Compós. Rio de Janeiro: PUC-Rio, 2010. p. 1-15.

SILVA, Renata Maldonado. Percursos históricos da produção do gênero telenovela no Brasil: continuidade, rupturas e inovações. Conexão (UCS), v. 11, p. 151-172, 2012.

THOMASSEAU, Jean-Marie. O melodrama. Tradução e notas Claudia Braga e Jacqueline Penjon. São Paulo: Editora Perspectiva, 2012.

WOTRICH, Laura, SILVA, Renata C. da; RONSINI, Veneza M. A perspectiva das mediações de Jesús Martín Barbero no estudo de recepção da telenovela. In: XXXII Congresso Brasileiro de Ciências da Comunicação, 2009, Curitiba, PR. Anais eletrônicos XXXII Intercom. Curitiba: Universidade Positivo, 2009. 
I Brasil. Ana Lúcia da Silva Enne. Doutora em Antropologia pelo PPGAS/MN/UFRJ, professora do curso de Estudos de Mídia e do Programa de Pós-Graduação em Cultura e Territorialidades da Universidade Federal Fluminense, Niterói, RJ. Contato: anaenne@gmail.com

II Brasil. Ohana Boy Oliveira. Doutoranda em Comunicação, Mestra em Cultura e Territorialidades e Bacharel em Produção Cultural pela Universidade Federal Fluminense. Contato: ohanaboy@gmail.com

III Brasil. Joana D'Arc de Nantes. Doutoranda em Comunicação, Mestre em Comunicação e Bacharel em Produção Cultural e Estudos de Mídia pela Universidade Federal Fluminense. Contato: joanadarc@id.uff.br

IV Metáfora utilizada por Jesús Martín-Barbero para definir sua trajetória no campo da comunicação.

V Vale ressaltar que, além da tradição de autores relacionados ao campo dos estudos culturais, existem diversas autoras que também trabalham com a perspectiva interdisciplinar e contra hegemônica, reconhecendo o perigo da história única e seguindo pelo caminho da descolonização do pensamento, dentre elas Gloria Anzaldúa, Grada Kilomba, Chimamanda Ngozi Adichie etc. Não vamos evocá-las nesse texto porque buscamos compreender a inserção de Martín-Barbero em uma tradição específica dos Estudos Culturais, como demonstraremos nesse artigo, mas consideramos importante nomeá-las.

VI Citação disponível na contracapa do livro em sua edição brasileira.

VII Importante ressaltar que muitos desses pesquisadores também têm uma trajetória interdisciplinar em sua formação, transitando pela filosofia, antropologia e comunicação, por exemplo, o que acaba atravessando seus trabalhos.

VIII O texto foi publicado no prefácio da $5^{a}$ edição espanhola do livro De los medios a las mediaciones. Comunicacion, cultura y hegemonía e está presente na $13^{a}$ edição brasileira, utilizada neste estudo.

IX A pesquisadora Maria Immacolata Vassalo Lopes se referiu à Jesús Martín-Barbero dessa forma em evento realizado em São Paulo em 2009. Disponível em: <http:// revistapesquisa.fapesp.br/2009/09/01/as-formas-mesticas-da-midia/>. Acesso em: 10 out. 2017.

$X$ Neste ponto percebemos mais uma alusão aos estudos de Nestor García Canclini, que apresenta certa afinidade teórica com Jesús Martín-Barbero, podendo ser considerado, ao nosso ver, um par acadêmico, como já indicamos anteriormente.

XI Não entraremos no âmbito da representação da cultura popular por não ser o escopo deste artigo, mas entendemos as inúmeras disputas que são constitutivas deste campo.

XII Texto original: "Y esta ambigüedad o pluri-significación de lo popular aparece porque esta da cuenta de muchas prácticas, procesos y experiencias diversas".

XIII Não foi possível no escopo deste trabalho desenvolver uma pesquisa que adentrasse nas competências de recepção e as mediações associadas a elas, no entanto, acreditamos que os aspectos da audiência e recepção transpassam nossas percepções e contribuições neste trabalho.

XIV Dados coletados em 20 nov. 2017. Disponível em: <http://www.citizengo.org/es/107372-dejen-emitir-papa-toda-madre>. Acesso em: 20 nov. 2017.

XV O SBT é muito ativo nas mídias sociais. Em 2010, foi a primeira emissora brasileira a ganhar o selo de autenticidade na página do Facebook (MARTINS, 2014 , p. 3) e, em 2017, se tornou o maior canal de TV do mundo no YouTube, alcançando a marca de 4 milhões de inscritos. Disponível em: <http://www.sbt. com.br/sbtnaweb/fiquepordentro/97244/SBT-se-torna-o-maior-canal-de-TV-do-mundo-no-Youtube.html>. Acesso em: 10 nov. 2017. 